\title{
THE INDIAN POLICY REVIEW COMMISSION
}

\author{
LlOYd MeEDS*
}

"Congress declares that it is timely and essential to conduct a comprehensive review of the historical and legal developments underlying the Indians' unique relationship with the Federal Government in order to determine the nature and scope of necessary revisions in the formulation of policies and programs for the benefit of Indians."1 With these profound words, the American Indian Policy Review Commission was born in the Ninety-third Congress. All of us in the field of Indian affairs in Congress have realized for some time that an organized study must be initiated and plausible legislation must be enacted to bring order and aid to the chaotic world of Indian affairs. It is clear that Congress has plenary power in Indian affairs. This power enables Congress to legislate, clarify, define, and create policy.

The unique relationship which exists between the United States and Indian tribes pre-dates the ratification of the Constitution. In 1754 the Albany Congress placed Indian affairs under auspices of the Congress. In 1775 the Continental Congress directed that three departments be established to exert a collective influence over the Indians. The Articles of Confederation, which became effective in 1781, gave " $[t]$ he United States in Congress ... the sole and exclusive right and power of . . . regulating the trade and managing all affairs with the Indians ... provided that the legislative right of any State within its own limits be not infringed or violated." 2 From the earliest history of our country the federal government has had authority over Indians and Indian tribes. The relationship established from the inception of this country, however, has no exact counterpart in the history of international or domestic law. This unique relationship has never been exactly defined. Therefore, the inconsistent history of governmental relations and the vague body of law related to the Indian field has made it impossible to find justice for Indians and non-Indians alike. Solomon would have wept had he to decide justice in present-day Indian affairs.

The federal policy implementing this relationship has shifted and changed with different administrations and passing years. These policies have included peacemaking diplomacy, armed conflict, tribal removal, subjugation, extermination, concentration, assimilation, termination, and self-determination-not

\footnotetext{
* United States Representative from Washington; Vice-chairman, American Indian Policy Review Commission.

1. Act of Jan. 2, 1975, Pub. L. No. 93-580, 88 Stat. 1910.

2. Articles of Confederation art. IX.
} 
necessarily in that order. Laws were piled upon laws without regard to the effect of the one upon the other. Programs have been initiated, terminated, replaced, and reinstituted without apparent rational design. In short, there exists a unique relationship between the United States and Indian tribes which has never admitted of an exact definition and which has never been implemented by a coherent, consistent policy.

Two major studies of Indian affairs were conducted during this century, primarily directed at the operations of the Bureau of Indian Affairs rather than at the totality of the relationship. In 1926, the Department of the Interior invited the Institute for Government Research to make a survey of the social and economic conditions of the Indians. In 1928, the Institute made a comprehensive report, known as the Meriam Report. ${ }^{3}$ The insights of this report were basically responsible for the major reform in Indian affairs in the early 1930s, including the Indian Reorganization Act of 1934. ${ }^{4}$

In the Eighty-second Congress, the Committee on Interior and Insular Affairs submitted House Resolution 698, which passed the House on July 1, 1952. ${ }^{5}$ The resolution directed and authorized the committee to make a full and complete investigation and report of the activities and operations of the Bureau of Indian Affairs. On December 15, 1952, the committee submitted its report to the House. ${ }^{6}$ The bitter fruit of this report was the termination era of the $1950 \mathrm{~s}$, which has been repudiated by the Ninety-third Congress, particularly in the Menominee Restoration Act of 1973. ${ }^{7}$

The end result has been that the federal programs to benefit Indians and the many dollars poured into them have been a comparative failure in eliminating basic Indian problems and placing Indian people on the road to self-sufficiency.

Admittedly, the United States owes a trust responsibility to Indian tribes, but no one can define that responsibility exactly or even agree on whether or not it should be given an exact definition. And although it is admitted that Indians and Indian tribes have certain rights, the morass of conflicting or duplicating laws makes it nearly impossible to render them the necessary protection.

Congress is now in a position to assess the role of history in Indian affairs, to view its own responsibility, and to be aware of the possible consequences of suggested legislative change. Through the American Indian Policy Review Commission it is hoped that a thorough study can be made and that new legislation can be recommended to a waiting Congress.

3. L. Meriam, The Problems of Indian Administration (1928).

4. Indian Reorganization Act of 1934, ch. 576, § 16, 48 Stat. 987.

5. H.R. Res. 698, 82d Cong., 2d Sess. (1952).

6. H.R. ReP. No. 2503, 82d Cong., 2d Sess. (1952).

7. Menominee Restoration Act of 1973, Pub. L. No. 93-197, 87 Stat. 770. 
Eleven task force study areas have been identified and three professionals have been assigned to each task force in order to perform the major functions of the Commission. ${ }^{8}$ The actual work of the task forces began in early August 1975. Other problem areas, such as housing, have been placed specifically within the jurisdictional confines of existing task forces. Although dependent on the individual capabilities, intellectual professionalism, and tenacity of the members of each task force, Congress hopes that the recommendations provided by each task force will clarify the congressional responsibility and will precipitate organized change.

The eleven task force study areas are:

1. Trust responsibility, and federal Indian relationship

2. Tribal government

3. Federal administration and structure of Indian affairs

4. Federal, state, and tribal jurisdiction

5. Indian education

6. Indian health

7. Reservation development

8. Urban, rural nonreservation

9. Indian law revision, consolidation, and codification

10. Terminated and nonfederally recognized Indians

11. Alcoholism and drug abuse

Fortunately, very fine candidates were nominated and excellent professionals have been appointed to these task forces. The Commissioners are anxious that this Commission receive national Indian support and have been most encouraged by the acceptance of well qualified people. Each Commissioner seems keenly aware of his or her responsibility to appoint the best qualified person to the task forces.

The structure of the Commission, the caliber of the Commission members and task force personnel, and the broad spectrum of the study all present the Congress with a unique opportunity to base American Indian policy squarely on solidly-based, factual conclusions.

8. S. 2073, 94th Cong., Ist Sess. (1975) permits voluntary services to be contributed to the work of the Commission. Act of Aug. 9, 1975, Pub. L. No. 94-80, 89 Stat. 415. 